\title{
THE SOUTHERN BRAZILIAN SHELF: GENERAL CHARACTERISTICS, QUATERNARY EVOLUTION AND SEDIMENT DISTRIBUTION
}

\author{
Michel Michaelovitch de Mahiques ${ }^{l, *}$, Silvia Helena de Mello e Sousa ${ }^{l}$,Valdenir Veronese Furtado ${ }^{l}$, \\ Moysés Gonsalez Tessler ${ }^{l}$, Felipe Antonio de Lima Toledo ${ }^{I}$, Leticia Burone ${ }^{I}$, Rubens Cesar Lopes Figueira ${ }^{l}$, \\ Daniel Andreas Klein ${ }^{2}$, Cristina Celia Martins ${ }^{3}$ and Daniel Pavani Vicente Alves ${ }^{1}$ \\ ${ }^{1}$ Instituto Oceanográfico da Universidade de São Paulo \\ (Praça do Oceanográfico, 191, 05508-120 São Paulo, SP, Brasil) \\ ${ }^{2}$ Atualmente na Conservação Internacional, Brasil \\ ${ }^{3}$ Atualmente na Companhia Ambiental do Estado de São Paulo (CETESB), Brasil \\ *Corresponding address: mahiques@usp.br
}

\begin{abstract}
A B S T R A C T
Extending from latitude $34^{\circ} \mathrm{S}$ to $22^{\circ} \mathrm{S}$ the Southern Brazilian shelf constitutes the only part of the Brazilian shelf with a subtropical to temperate environment. The studies on the different geological aspects of the area began in the 1960's and have recently been reassessed after studies related to the determination of the Economic Exclusive Zone. In terms of morphology, the Southern Brazilian shelf may be divided into three sectors, the São Paulo Bight, the Florianópolis-Mostardas Sector and the Rio Grande Cone, characterized by conspicuous differences in terms of geological determining factors, bathymetry, declivities and the presence of canyons and channels. Despite the existence of hundreds of radiocarbon datings the sea level changes curve of southern Brazil during the Last Glacial Cycle is still a matter of debate. A recent controversy on the Middle and late Holocene sea level changes curve raised the question of the amplitude of the oscillations which occurred in the period. Also, a few but relatively consistent radiocarbon datings suggest the occurrence of a high sea level during Isotope Stage 3. In terms of sedimentary cover the Southern Brazilian shelf exhibits a very strong hydrodynamic control, both latitudinal and bathymetrical. The sector southward from $25^{\circ} \mathrm{S}$ is characterized by the influence of the plume of water carrying sediments originating from the Río de La Plata. Actually its presence is conspicuous up to $28^{\circ} \mathrm{S}$, with the area between this latitude and $25^{\circ} \mathrm{S}$ constituting a transitional zone. In terms of bathymetry the outer shelf is marked by the "floor-polisher" effect of the Brazil Current, which is responsible for the maintenance of a relict facies in areas deeper than 100 meters.
\end{abstract}

\section{RESUMO}

Estendendo-se entre as latitudes $34^{\circ} \mathrm{S}$ e $22^{\circ} \mathrm{S}$, a plataforma continental sul-brasileira constitui o único setor que corresponde a um ambiente subtropical a temperado. Os estudos dos diferentes aspectos geológicos da área iniciaram-se na década de 1960 e foram recentemente retomados após os trabalhos relativos à delimitação da Zona Econômica Exclusiva. Em termos de morfologia, pode ser dividida em três setores: Embaiamento de São Paulo, Setor Florianópolis-Mostardas e o Cone do Rio Grande, cada qual definido com base em diferenças geológicas relativas a batimetria, declividade e a presença de cânions e canais. A despeito da existência de centenas de datações ao radiocarbono, a curva de variações relativas do nível do mar no Último Ciclo Glacial é ainda tema de debate. Controvérsia recente sobre as curvas de variação do nível do mar sobre as durante o Holoceno Médio e Tardio trouxe à tona a questão da amplitude das oscilações do nível do mar. Adicionalmente, poucas mas consistentes datações sugerem a ocorrência de um nível do mar elevado durante o Estágio Isotópico 3. Em termos de processos sedimentares atuais, a plataforma continental sul-brasileira exibe um controle hidrodinâmico muito forte, tanto latitudinal quanto batimétrico. O setor ao sul de $25^{\circ} \mathrm{S}$ é caracterizado pela influência da pluma de água que carreia sedimentos originários do Rio da Prata, cuja presença é conspícua até $28^{\circ} \mathrm{S}$, havendo uma zona de transição entre essas duas latitudes. A plataforma externa é marcada pelo "efeito enceradeira" da Corrente do Brasil, relíquia responsável pela manutenção de uma fácies em áreas além da isóbata de 100 metros.

Descriptors: Continental shelf, Sedimentation, Sea level changes, Last glacial cycle.

Descritores: Plataforma continental, Sedimentação, Variações do nível do mar, Último ciclo glacial. 


\section{INTRODUCTION}

Extending approximately from latitude $34^{\circ} \mathrm{S}$ to $22^{\circ} \mathrm{S}$ and covering almost 270,000 sq. $\mathrm{km}$, the Southern Brazilian shelf constitutes a very good example of a hydrodynamically-determined modern shelf (MAHIQUES et al., 2004) and corresponds to the only part of Brazil with a subtropical to temperate environment (ROCHA et al. 1975) (Fig. 1).

The systematic study of the southern Brazilian shelf started in the 1960's with bathymetric, seismic and sedimentological studies of the REMAC Project (Global Reconnaissance of the Brazilian Continental Margin) which still represent, for some areas, the only available source of information on the geology and geophysics of the Brazilian margin (see Milliman and Barreto 1975, and related papers). More recently, sedimentological and bathymetrical works have been incorporated under the auspices of the REVIZEE project (Living Resources of the Brazilian Economic Exclusive Zone) (FIGUEIREDO and TESSLER 2004; FERREIRA et al., 2005). Nevertheless, because of its size there are considerable gaps in the scientific geological communitys' knowledge of the area and the evolutionary processes of the shelf, especially as related to the Last Glacial Cycle, still deserving of more detailed study.

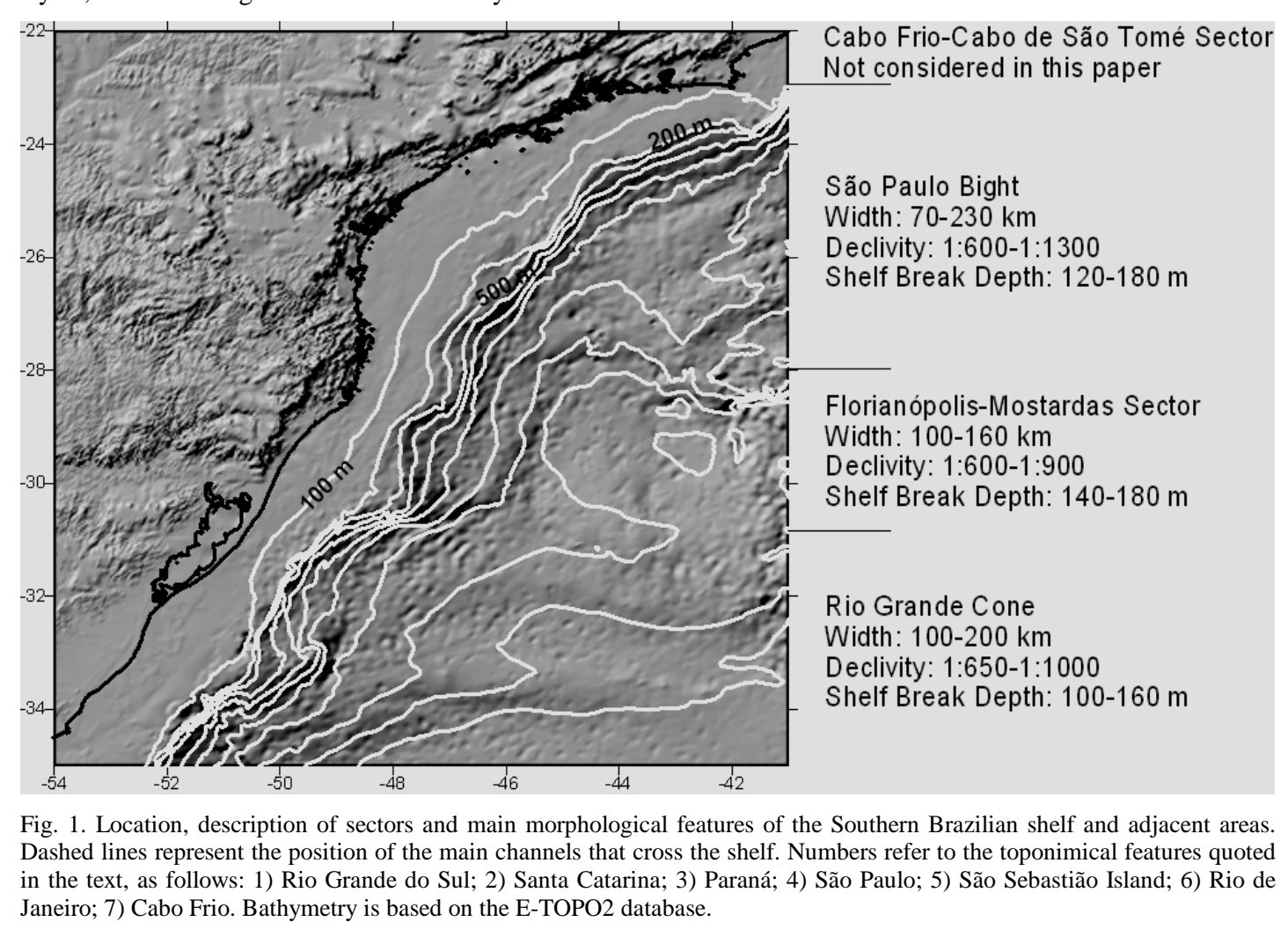

Fig. 1. Location, description of sectors and main morphological features of the Southern Brazilian shelf and adjacent areas. Dashed lines represent the position of the main channels that cross the shelf. Numbers refer to the toponimical features quoted in the text, as follows: 1) Rio Grande do Sul; 2) Santa Catarina; 3) Paraná; 4) São Paulo; 5) São Sebastião Island; 6) Rio de Janeiro; 7) Cabo Frio. Bathymetry is based on the E-TOPO2 database. the art of the knowledge of the main geological/geomorphological characteristics, with a special emphasis in the Quaternary sedimentary evolution and distribution of the modern sediments.

\section{General Characteristics}

Table 1 and Figure 1 summarize the main characteristics of the Southern Brazilian Shelf.

The Southern Brazilian Shelf has been described from the geomorphological point of view by Zembruscki (1979) who divided the area into four sectors: the Cabo Frio-Cabo de São Tomé Sector, the São Paulo Bight, the Florianópolis-Mostardas Sector and the Rio Grande Cone. For the objective of this paper, only the last three sectors are dealt since the insertion of the Cabo-Frio-Cabo de São Tomé Sector in the scope of the Southern Brazilian Shelf may be considered at least controversial, due to its different geomorphological, hydrodynamic and sedimentological characteristics, when compared with the areas located southward. The main characteristics of the Southern Brazilian Shelf are summarized in Table 1 and Figure 1. 
Table 1. Summary of the main characteristics of the Southern Brazilian shelf.

\begin{tabular}{|l|l|}
\hline Shelf Area & $267,000 \mathrm{sq} . \mathrm{km}$ \\
\hline Width of the shelf & 50 to $230 \mathrm{~km}$ \\
\hline Tidal range & Less than 2.0 meters \\
\hline Waves & 0.0 to 5.0 meters \\
\hline & $\begin{array}{l}\text { Waves on the inner shelf } / \\
\text { Currents on the outer shelf }\end{array}$ \\
\hline Dominating process & $150 \mathrm{~m}$ \\
\hline Average depth of the shelf break & Siliciclastic (95\%) \\
\hline Siliciclastic/carbonate/autigenic/glacial sedimentation & Modern (50\%) and relict/palimpsest (50\%) \\
\hline Modern/relict/palimpsest & Stable \\
\hline Tectonic trend over theLast Glacial Cycle &
\end{tabular}

The São Paulo Bight corresponds to the arcshaped sector, ranging from latitude $22^{\circ} \mathrm{S}$ to $28^{\circ} \mathrm{S}$. The shelf width varies between 70 and $230 \mathrm{~km}$, with declivities varying from 1:600 to 1:1,300, and shelf break is located between 120 and $180 \mathrm{~m}$. In terms of local features this sector is characterized by the presence of channels (i.e., Rio de Janeiro, Ilha Grande, Buzios and Cananéia), which may or may not be related to deeper canyons present on the continental slope, and they represent the main drainage systems developed during low sea level periods.

The Florianópolis-Mostardas Sector, in its turn, corresponds to a convexity of the coastline. The isobaths and its characteristics are related to the Ponta Grossa Arc, extending from latitude $28^{\circ} \mathrm{S}$ to $31^{\circ} \mathrm{S}$. Shelf width varies from 100 to $160 \mathrm{~km}$, with declivity ranging from 1:600 to 1:900, and shelf break is located between 140 and $180 \mathrm{~m}$. This is the most regular sector of the Southern Brazilian Shelf, with no marked channels and with a single prominent scarp, without sedimentary deposits associated.

The Rio Grande Cone sector constitutes the southernmost and most irregular sector of the Southern Brazilian shelf. Its width varies from 100 to $200 \mathrm{~km}$, with average declivity ranging from 1:650 to 1:1,000, with shelf break lying at between 100 and $160 \mathrm{~m}$. It is characterized by the presence of elongated sand banks, topographical heights up to $30 \mathrm{~m}$, and two 10-meter high scarps, located along the 110-m and 60$\mathrm{m}$ isobaths which have been associated with the sea level stabilization periods of the Last Glacial Maximum (LGM) and of the 11,000 years B.P. Event (probably related to Younger Dryas, respectively.

\section{The Quaternary Evolutionary History OF The BraziLIan CoAst \\ Relative Sea-level Changes}

The Quaternary sea-level changes are among the main factors that have determined the evolution of the Brazilian coastal plain and shelf. Evidences of sealevel changes have been cited by several authors since the $19^{\text {th }}$ century (HARTT, 1870; BRANNER; 1904), but initially these changes were studied from a geomorphological point of view and assumed to be Tertiary in age. Only after the 1960's and, more frequently during the 1970's and 1980's, with systematic studies undertaken from the coast of Rio Grande do Sul (S Brazil) to Alagoas (NE Brazil), and with thousands of radiocarbon datings have the Holocene relative sea-level change curves for different sectors of the Brazilian coast been determined (SUGUIO et al., 1985; ANGULO et al., 2006).

The evidences for such changes are of three types: morphological, biological and archeological. The morphological evidence is represented by marine deposits located above the present sea-level, as well as by submerged terraces and scarps on the shelf. Systematic geological mapping has enabled the distinction of several generations of sandy terraces constructed after the maximum sea-levels related mainly to the Cananéia / Barrier ("beach barrier") III (=Penultimate=Eemian) and Santos / Barrier IV (=Holocene) transgressions.

The biological evidence is represented by vermetidae (intertidal dwellers), oyster and coral incrustations, sea-urchin holes, and Callichirus (Crustacea) burrows, all of them with quite good control on their position related with sea level or tidal range.

Archeological evidence is represented by hundreds of shell-middens ("sambaquis") created by the ancient inhabitants of the coastal zone, found on the southern and southeastern Brazilian coast. The composition of the sambaquis, some of them located as far as $30 \mathrm{~km}$ from the present coastline, suggests that these deposits were constructed close to the shoreline (lagoons, estuaries).

There is relative agreement as to the position of the sea-level for the Isotope Stage 5e and older transgressive events. Since there are few datings specifically for the Southern Brazilian coast, most of the data here presented is related to correlation with sea-level change curves from other coasts.

In contrast, the position of the sea level for the last 40,000 years is still open to discussion, as summarized in Figure 2, especially for the last 7,000 years. There is a consensus among the authors that a mid-Holocene sea-level highstand occurred along the 
whole coast, followed by a drop to present time. However, it is still controversial if the drop in sealevel was continuous or not (see Angulo; Lessa 1997;
Angulo et al., 1999, 2006; Martin et al., 1998, 2003, for recent discussions on this topic).

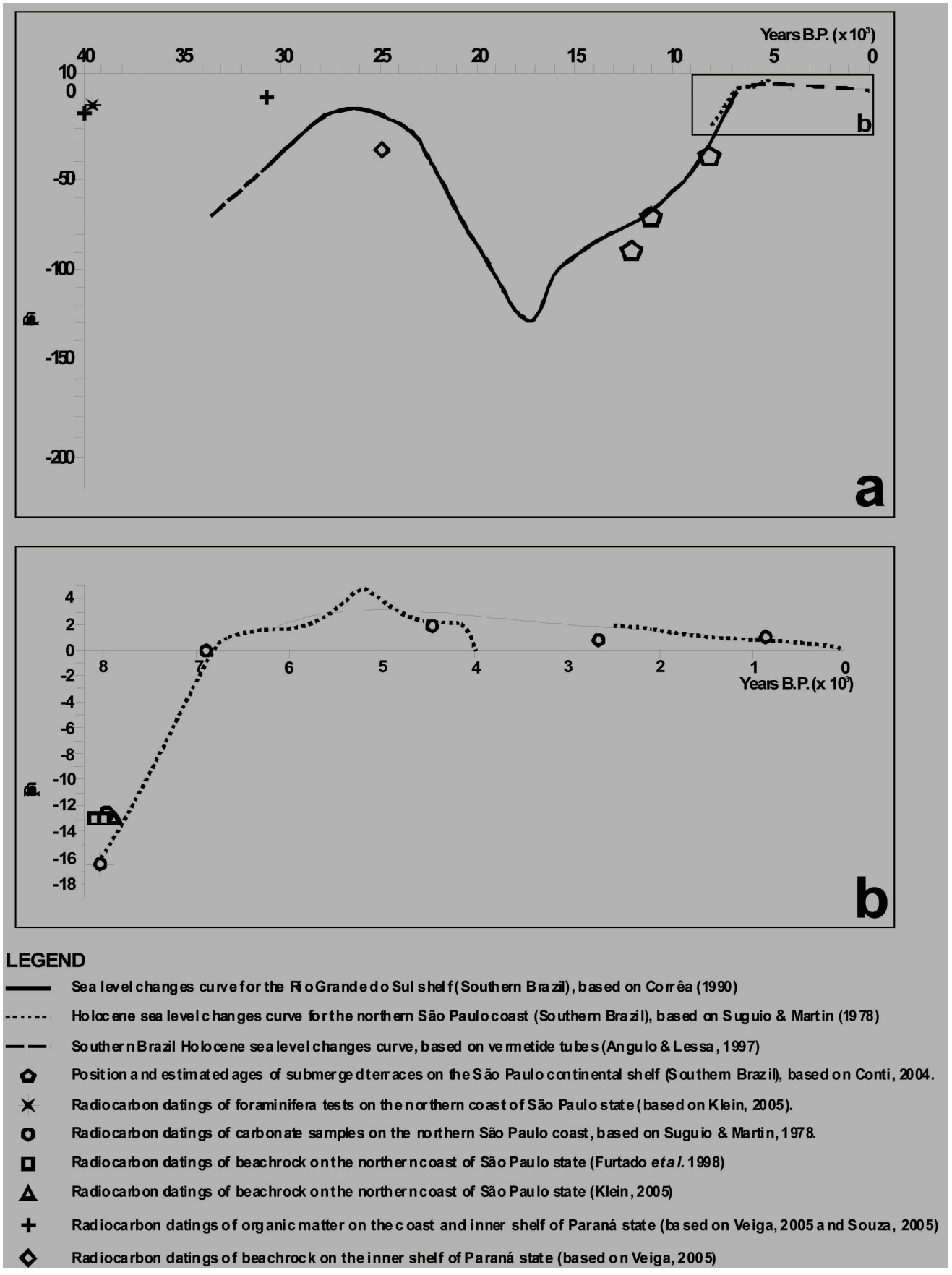

Fig. 2. a) Compilation of the available sea level change curve, showing isolated data for the last 40,000 years on the Southern Brazilian shelf and coast; b) Detailed curves and isolated data for the Middle and Late Holocene. 
High sea-levels before 120,000 years B.P.

Two high sea-levels, probably older than 120,000 years B.P., are only well represented on the coastal plain of the State of Rio Grande do Sul. Villwock et al. (1986) assumed these levels to be Middle (Yarmouth?) and Lower (Aftonian?) Pleistocene in age and named them, respectively, as Barrier II and Barrier I. Scattered across the coastal plains of the states of Santa Catarina, Paraná and probably São Paulo, there are some sandy or gravely (more than 13 meter-high) terraces, of probable marine origin, which might be correlated with Barrier II. No evidence of an ancient sea-level related to Barrier I has been found anywhere else.

\section{High sea-level of 120,000 years B.P. (Oxygen Isotope Stage 5e)}

At that time the relative sea-level was probably situated $8 \pm 2 \mathrm{~m}$ above the present sea-level. This high sea-level episode is known as the Cananéia Transgression on the coastal plain of the São Paulo State (SE Brazil) (SUGUIO; MARTIN 1978), and as the penultimate Transgression on the coastal plains of the states of Bahia, Sergipe and Alagoas (NE Brazil) (BITTENCOURT et al., 1979). This episode generated deposits named Barrier III on the coast of Rio Grande do Sul (S Brazil) (VILLWOCK et al., 1986). The age of this transgression has been established through five datings obtained from coral samples, collected from the basal portion of marine terraces in the coastal plain of the State of Bahia (NE Brazil), using the Io/U method (MARTIN et al., 1982). Although very well preserved in certain areas, such as the Cananéia and Paranaguá coastal plains the outcrops of this formation on the southern coasts of Brazil have not yielded any material which could be dated with confidence as regards absolute ages.

The stratigraphy of the Quaternary sedimentary deposits of the Cananéia-Iguape coastal plain (SE Brazil) was first described by Petri and Suguio (1971, 1973) and Suguio and Petri (1973) and may be taken as a reliable model for the Late Pleistocene evolution of the Southern Brazilian coast. Those researches were based their findings mainly on field observations and borehole data. The authors subdivided the sedimentary column into four main sequences:

a) Sequence $\mathbf{I}$ - formed of sands and conglomeratic sands containing clay levels. Its thickness may reach up to $118 \mathrm{~m}$, observed in a borehole.

b) Sequence II - composed of silty clays rich in diatoms but very poor in foraminifers. The sequence was interpreted as characteristic of a mixohaline environment.

c) Sequence III - formed of silty sands superimposed on Sequence II and rich in well-preserved foraminifers. Its thickness varies from 7 to $12 \mathrm{~m}$, Iinterpreted as been deposited in a shallow shelf environment.

d) Sequence IV - represented by 20 to $30 \mathrm{~m}$ of fine to very fine well-sorted sand, with wide horizontal distribution over the whole Cananéia-Iguape coastal plain area. These sands have been intensively reworked and constitute the sediment source of the modern beaches in the area.

Sequence I has been correlated to the Tertiary continental deposits of the Pariqüera Açu Formation studied by Bigarella et al. (1965) and Melo (1990). Sequences II and III have been attributed to a transgressive phase while Sequence IV represents a regressive deposit, named as Cananéia Formation. Later, Sequences II, III, and IV were incorporated into the Cananéia Formation (MARTIN; SUGUIO, 1978).

The altitudes of the Cananéia Formation deposits vary from 5-6 m close to the ocean to 9-10 m in the vicinity of the crystalline basement rocks.

\section{Isotope Stage 3}

Based on a core, sampled in the São Sebastião region (São Paulo coast), Klein (2005) reported the existence of a mixohaline to freshwater sequence, located $7 \mathrm{~m}$ below present sea-level, with radiocarbon ages that may be associated with Isotope Stage 3 (Fig. 2a). This sequence consists of muds with foraminifers and ostracodes, radiocarbon-dated at 39,500 cal years B.P., with a progressive reduction in marine components up to a complete freshwater environment beginning at ca 25,000 years B.P.

On the Paraná inner shelf, Veiga (2005) found a muddy sequence at 13 to $12 \mathrm{~m}$ below present sea level, with the presence of the foraminifera Blymasphaera brasiliensis, typical of mixohaline environments, with two radiocarbon datings of 40,600 and 46,700 cal years B.P.. This is consistent with the observations of Souza (2005) who obtained a radiocarbon age of 30,900 cal years B.P. for a strata located $8 \mathrm{~m}$ below present sea level on the adjacent coastal plain.

Finally, Veiga (2005), obtained a radiocarbon dating of 25,000 cal years B.P. in a beachrock located between 33 and $31 \mathrm{~m}$ below present sea level on the inner shelf of the Paraná coast.

Despite several authors' having reported problems of contamination with young carbon in older materials datings the consistence of the radiocarbon datings related to all these examples may be used as an argument for the reliability of the data. Thus it is possible to admit that during Isotope Stage 3 southern Brazilian shelf sea level was higher than expected. The causes for this trend still deserve closer analysis, since this is a non-glaciated, tectonically stable area. 


\section{Last Glacial Maximum and Early Holocene}

The scarcity of datings and reliable sea-level indicators is the main characteristic of the sea-level curves of the Southern Brazilian shelf from the Last Glacial Maximum up to 7,000 years B.P. Most of the papers correlate the morphosedimentary features such as submerged terraces with global sea-level change curves, the paper of Correa (1996) being one of the exceptions. According to the latter, the LGM coastline was located at a depth of $130 \mathrm{~m}$ below present sea-level, followed by three intermediary stabilization periods, at 11,000 years B.P. (between 60 and $-70 \mathrm{~m}$ ), 9,000 years B.P. (between -32 and -45 $\mathrm{m})$ and 8,000 years B.P. (between -20 and $-25 \mathrm{~m}$ ).

The 11,000 years B.P. stabilization event has also been found on the Abrolhos shelf (Eastern Brazil), represented by a lagoonal environment (VICALVI et al., 1978). In the State of São Paulo, an age of 7,470 $\pm 60 \mathrm{cal}$ years B.P. was found in a mollusk shell collected in a paleo-beach sediment located $6 \mathrm{~m}$ below present sea-level (MAHIQUES; SOUZA, 1999). Also, four beach rock samples, located $13 \mathrm{~m}$ below present sea-level were radicarbon dated in $8,000 \pm 50$ cal years B.P. and constitute some of the few sure and well dated information on sea level stabilization periods prior to the maximum sea-level at 5,100 years B.P. (KLEIN, 2005).

Finally, Conti (2004) correlated the position of submerged terraces on the São Paulo State continental shelf with Correa's (1996) data and establishes minor differences of the sea-level curve between 12,000 and 8,000 years B.P.

\section{Middle and Late Holocene sea-level (Fig. 2B)}

On top of the Pleistocene sediments and a no higher than $4 \mathrm{~m}$ altitudes, other sandy deposits occur. These deposits are less extensive in area but form an almost continuous zone between Pleistocene deposits and the sea, and exhibit very clear structures of alignment of beach ridges. Further inland clayeysandy sediments were deposited in places where the Pleistocene deposits had been eroded. These sediments are related to the Santos (Holocene) transgression event, the maximum of which occurred ca. 5,600 cal years B.P. (MARTIN et al., 2003).

The most recent high sea-levels have been defined by virtue of numerous reconstructions of recent sea-levels in space and time, carried out using more than 700 radiocarbon datings (SUGUIO et al., 1985; ANGULO; SUGUIO, 1995). Moreover, the positions of some shell-middens, together with a comparison of the radiocarbon ages and $\delta^{13} \mathrm{C}$ values of mollusk shells, have supplied very interesting additional information on relative sea-level fluctuations during the last 6,000 years (FLEXOR et al., 1979). The utilization of these data has permitted the delineation of complete or partial relative sea-level fluctuation curves for several sectors of the Brazilian coast. More recently Angulo and Lessa (1997) and Angulo et al. (1999) have criticized the former curves and proposed a new Holocene sea-level changes model for the Brazilian coast based exclusively on vermetide tubes (Fig. 2b). The main controversy related to these curves is associated with the magnitude of the sea-level oscillations during this period, the first curve model admits two or three periods of sea-level lower than the present after 5,100 years B.P., and the second model assumes that the present sea-level constitutes the lowest level of the last 7,000 years.

Finally, Villwock and Tomazelli (1989) suggested the occurrence of a minimum of $-1.5 \mathrm{~m}$ below present sea-level at 1,500 years B.P., with a progressive rise up to the present. This trend has been established solely for the Rio Grande do Sul coastal plain and no correspondence with it has yet been shown to exist anywhere else on the Brazilian coast.

\section{Present Sedimentation}

The present sedimentation on the southern Brazilian shelf is dominated by oceanic water mass dynamics and shelf circulation. The hydrodynamic processes determine primary productivity and sediment redistribution on the shelf, leading to the establishment of geographical differences in sedimentation rates and sedimentary faciology.

The modern sedimentation rates vary from 5 to $660 \mathrm{~mm}$ kyr-1. Low sedimentation rates values relate to the outer shelf and are associated with the main flow of the Brazil Current, which acts as a "floor-polisher" on the sea bottom (MAHIQUES et al., 2002). Higher rates are correlated with areas of higher primary productivity, such as Cabo Frio $\left(23^{\circ} \mathrm{S}-\right.$ $42^{\circ} \mathrm{W}$ ), and/or terrigenous input, such as that on the shelf off Santa Catarina $\left(26^{\circ} 30^{\prime} \mathrm{S}-4^{\circ} 30^{\prime} \mathrm{W}\right)$ (MAHIQUES et al., 2004, 2005).

The sedimentation in the area may be analyzed either from a latitudinal or a bathymetric point of view. In terms of latitudinal changes there are two major limits to sediment distribution. The São Sebastião Island area $\left(24^{\circ} \mathrm{S}-45^{\circ} 30^{\prime} \mathrm{W}\right)$ marks the limit between two sedimentary zones characterized by differences in the organic and inorganic sediment fractions (Fig. 3).

Southward from this limit the depositional processes are related to the penetration of the plume of shelf water associated with the La Plata river runoff, with contributions from the southern Brazilian coastal lagoons. This low-salinity, low temperature water mass carries modern sediments and organisms from the La Plata estuary and the Argentinian shelf as far north as $24^{\circ} \mathrm{S}$ (PIOLA et al., 2000). Also, the interaction between the plume and the meandering processes of the Brazil Current as well as shelf 
morphology favour the establishment of high productivity zones, with correspondingly high sedimentation rates.

In fact, more recent and unpublished studies dealing with lead and neodymium isotopes indicate that the influence of the La Plata estuary is effectively limited to $28^{\circ} \mathrm{S}$, the sector between the latitudes $28^{\circ} \mathrm{S}$ and $24^{\circ} \mathrm{S}$ constitute a transitional zone (Fig. 3).

Northward from $24^{\circ} \mathrm{S}$ the relative heterogeneity of sediments is related to more complex hydrodynamics, especially on the middle and inner shelves, where bottom morphology, the presence of islands and the shape of the coastline lead to the establishment of a complex sedimentary mosaic.

There is also a conspicuous bathymetrical control of the sedimentary processes. On the inner shelf the Holocene sedimentation fills the irregular relief developed during the low sea-level stages (Fig. 4). Shallow seismic profiles reveal that this sedimentation may reach up to almost ten $\mathrm{m}$ in some areas. The Holocene sedimentary column obtained on the southern Brazilian shelf reveals a considerable variability both in grain size and sediment composition (carbonate calcium, organic carbon and elemental contents, i.e. $\mathrm{Al}, \mathrm{Ba}, \mathrm{Fe}, \mathrm{Ti}$ ), indicating that the sediment input and current strength were affected in the last ca. 7,000 years by changes in the wind and La Plata river discharge, probably related to subMilankovitch oscillations (MAHIQUES et al., 2009) (Fig. 5).

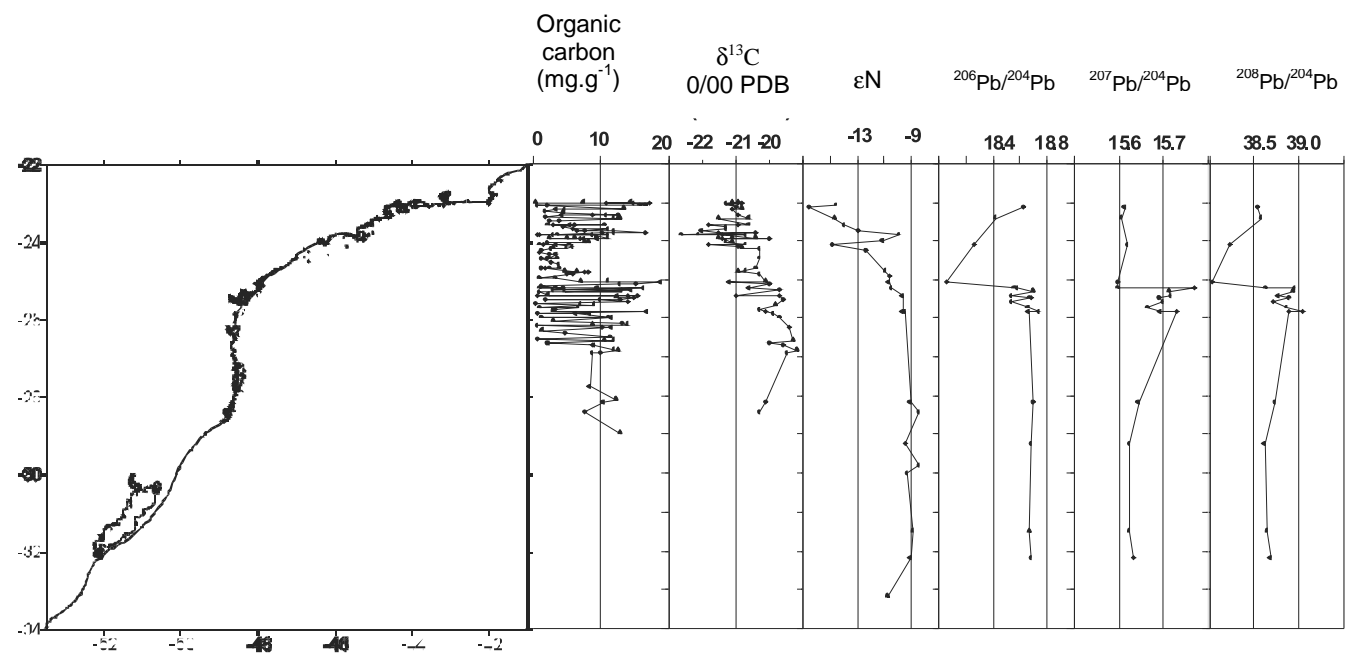

Fig. 3. Latitudinal variations of selected geochemical parameters, obtained from coretop samples. Some of these data are available in Mahiques et al. (2004).

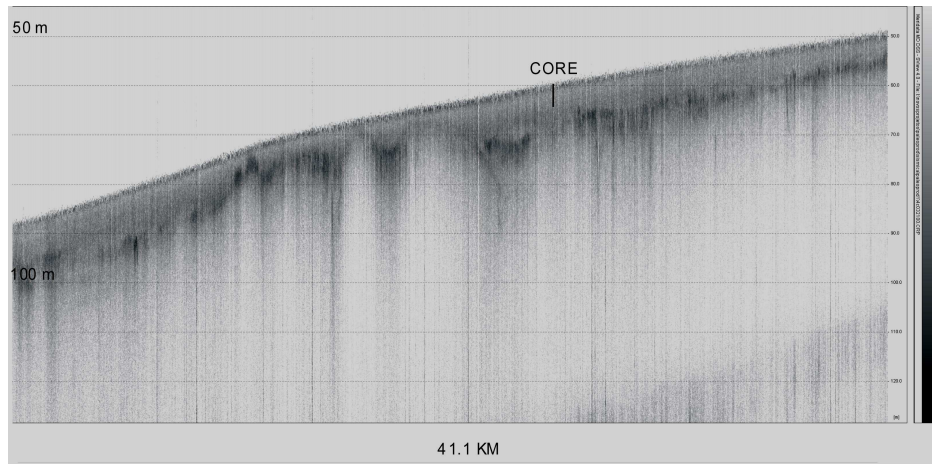

Fig. 4. Shallow seismic ("chirp") profile across the middle shelf off Santa Catarina, exhibiting the variations of Holocene sediment thickness over a rough Pleistocene substrate. Dotted lines mark depth intervals of $10 \mathrm{~m}$. See Figure 5 for core characteristics. 
On the outer shelf the bottom characteristics result from a more intense action of the meandering of the Brazil Current with the exposure of relict surfaces in extensive areas (MAHIQUES et al., 2002). This is clearly observed along the whole shelf as far south as $28^{\circ} \mathrm{S}$, where seismic and echo-sounding profiles reveal the existence of a rough surface (Fig. 6) and ages of as old as 2,060 yr B.P. are found in non-hermatypic corals sampled in coretops.

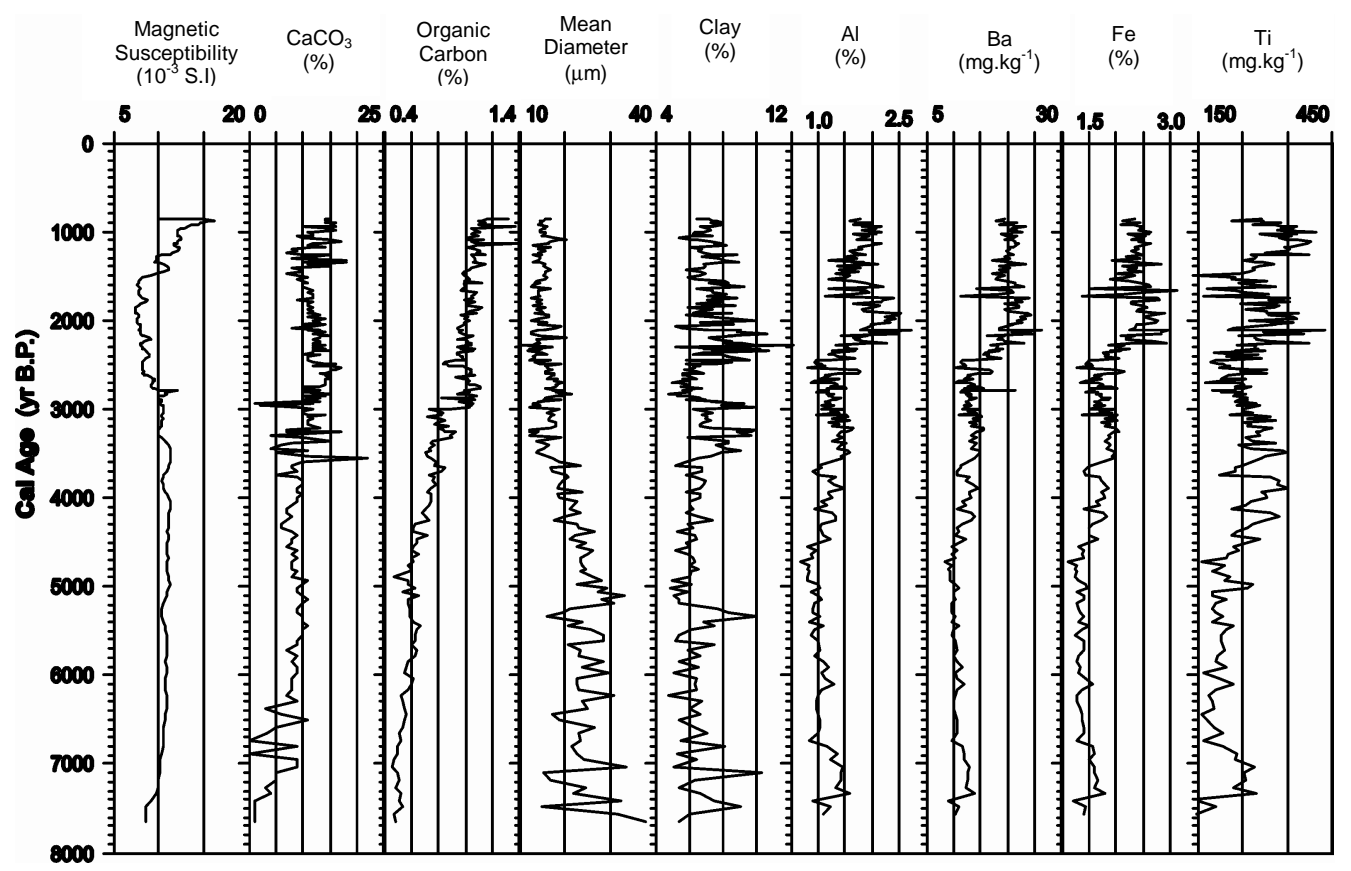

Fig. 5. Holocene variations in grain size and selected geochemical parameters in a core collected on the Santa Catarina shelf, at a depth of $60 \mathrm{~m}$ (see Figure 4 for position).

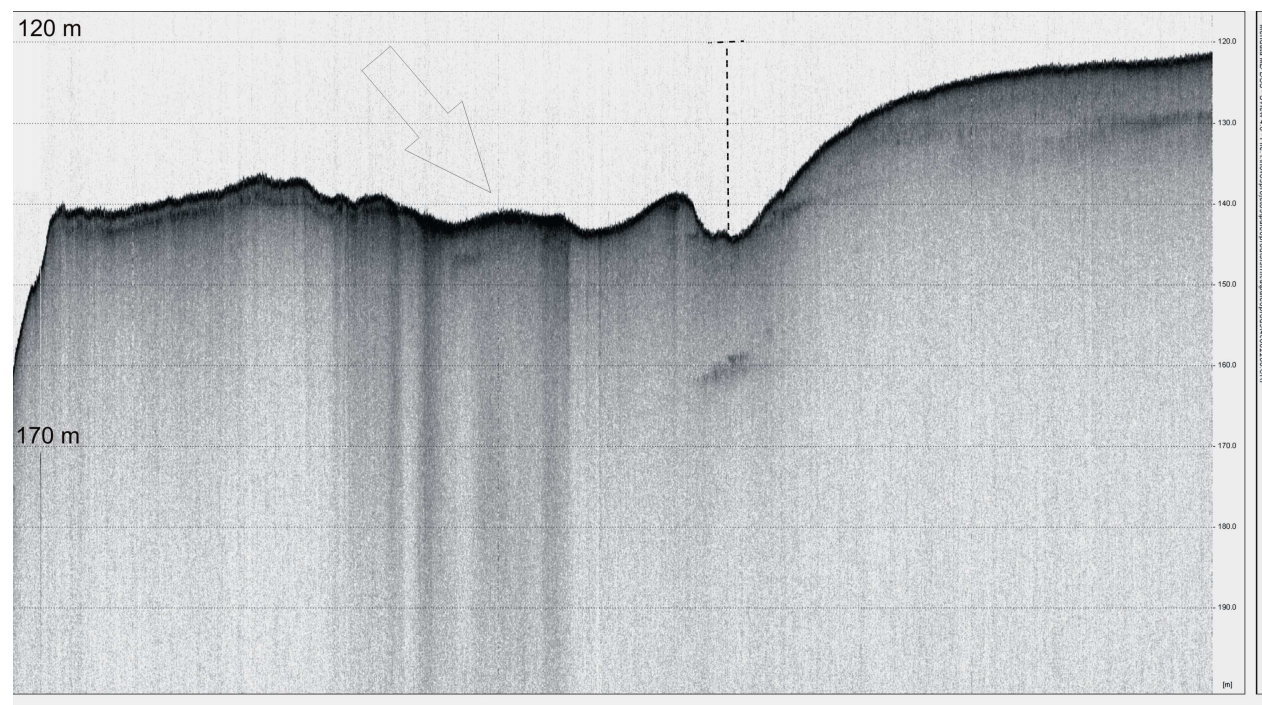

$39.4 \mathrm{~km}$

Fig. 6. Shallow seismic ("chirp") profile across the middle and outer shelf of São Paulo, showing the transition between depositional and relict facies. The relict facies has been maintained due to the "floorpolisher" effect of the Brazil Current. Dotted lines mark depth intervals of 10 meters and the arrow shows the relict facies, bar at the right indicates its limit approximately. 


\section{Final Remarks}

Scientific knowledge concerning of the Southern Brazilian shelf varies enormously. Although there is quite good comprehension of the geological structures, especially by virtue of the investments made by the oil industry, there is a lack of knowledge of the sedimentary processes which have occurred during the Last Glacial Cycle.

The number of available long cores, which may reach down to the Pleistocene strata, below Holocene sediments, is very small, as well as is that of the high resolution shallow seismic profiles.

As has been stressed in this paper, there is still much controversy about the sea level change curve, even for the Middle and Late Holocene, despite the number of radiocarbon datings for this period.

Nevertheless, due to its position and geomorphological configuration the Southern Brazilian shelf appears to be a key area for the study of the paleoclimate of South America. Detailed information on the oscillations of the wind regime and humidity may be acquired through high resolution studies in selected areas.

Finally, due to its tectonic stability and nonglaciated character the Southern Brazilian shelf may also be considered a favourable area for studies on sea-level changes during the Last Glacial Cycle.

\section{ACKNOWLEDGEMENTS}

This work is a contribution of the Brazilian representatives on the IGCP-464 and IGCP526 Projects. Thanks are due to Dr Allan Chivas (University of Wollongong, Australia) and $\mathrm{Dr}$ Francesco Latino Chiocci (Universitá di Roma "La Sapienza", Italy) for the opportunities given during the development of the project.

The authors are also indebted to the Fundação de Amparo à Pesquisa do Estado de São Paulo (Fapesp) and the Conselho de Desenvolvimento Científico e Tecnológico (CNPq), for the financial support provided for the studies on the continental shelf.

\section{REFERENCES}

ANGULO, R. J.; LESSA, G. C. The Brazilian sea-level curves: a critical review with emphasis on the curves from the Paranaguá and Cananéia regions. Mar. Geol., v. 140, p. 141-166, 1997.

ANGULO, R. J.; SUGUIO, K Re-evaluation of the Holocene sea-level maxima for the State of Parana, Brazil. Palaeogeogr. Palaeoclimatol. Palaeoecol., v. 113, p. 385-393, 1995.
ANGULO, R. J.; GIANNINI, P. C. F * SUGUIO, K.; PESSENDA, L. C. R. Relative sea-level changes in the last 5500 years in southern Brazil (Laguna-Imbituba region, Santa Catarina State) based on vermetid ${ }^{14} \mathrm{C}$ ages. Mar. Geol., v. 159, p. 323-339, 1999.

ANGULO, R J ; LESSA, G C * SOUZA, M C DE A critical review of mid- to late-Holocene sea-level fluctuations on the eastern Brazilian coastline. Quat. Sci. Revs, v. 25, p. 486-506, 2006.

BIGARELlA, J. J.; MOUSINHO, M. R.; SILVA, J. X. Pediplanos, pedimentos e seus depósitos correlativos no Brasil. Bolm parana. Geogr., v. 16/17, p. 117-151, 1965.

BITTENCOURT, A. C. S. P.; MARTIN, L.; VILAS-BOAS, G. S.; FLEXOR, J. M. Quaternary marine formations of the coast of the state of Bahia, Brazil. In: INTERNATIONAL SYMPOSIUM ON COASTAL EVOLUTION IN THE QUATERNARY, São Paulo, 1979. Proceedings ... São Paulo: Brazilian Geological Society, 1979. p. 232-253.

BRANNER, J. C. The stone reefs of Brazil, their geological and geographical relations. Bull. Mus. comp. Zool. Harv., v. 44, p. 7, 1904.

CONTI, L. A. Geomorfologia da plataforma continental do Estado de São Paulo. 2004. 179 p. Thesis. University of São Paulo, 2004.

CORREA, I. C. S. Les variations du niveau de la mer durant les dreniers 17.500 ans BP: l'exemple de la plate-forme continentale du Rio Grande do Sul - Brésil. Mar. Geol., v. 130 , p. $163-178,1996$

FERREIRA, C. S.; MADUREIRA, L. S. P.; KLIPEL, S.; WEIGERT, S.; HABIAGA, R. G. P.; DUVOISIN, A. C. Mapas do relevo marinho das regiões sudeste, sul e central do Brasil: acústica e altimetria por satélite. São Paulo: Institute of Oceanography of the University of São Paulo, 2005. p. 1-40. Série Documentos REVIZEE: Score Sul, p. 1- 40. 2005

FIGUEIREDO, A. G.; TESSLER, M. G. Topografia e composição do substrato marinho da região SudesteSul do Brasil. São Paulo: Institute of Oceanography of the University of São Paulo, 2004. Série Documentos REVIZEE: Score Sul, p. 1-64.

FLEXOR, J. M.; MARTIN, L.; SUGUIO, K. Utilisation du rapport isotopique ${ }^{13} \mathrm{C} /{ }^{12} \mathrm{C}$ comme indicateur d'oscillations lagunaires. In: INTERNATIONAL SYMPOSIUM ON COASTAL EVOLUTION IN THE QUATERNARY, São Paulo, 1979. Proceedings... São Paulo: Brazilian Geological Society, 1979. p. 358-375.

HARTT, C. F. Geology and physical geography of Brazil. Boston: Fields, Osgood, 1870. 625 p.

KLEIN, D. A. Registros de variações ambientais no Canal de São Sebastião (Estado de São Paulo), durante o Último Ciclo Glacial. 2005. 85 p. Thesis - University of São Paulo, 2005.

MAHIQUES, M. M.; SOUZA, L. A. Shallow seismic reflectors and upper Quaternary sea level changes in the Ubatuba region, São Paulo State, Southeastern Brazil. Rev. Bras. Oceanografia, v. 47, p. 1-10, 1999.

MAHIQUES, M. M.; SILVEIRA, I. C. A.; SOUSA, S. H. M. RODRIGUES, M. Post-LGM sedimentation on the outer shelf - upper slope of the northernmost part of the São Paulo Bight, southeastern Brazil. Mar. Geol., v. 181, p. 387-400, 2002. 
MAHIQUES, M. M.; TESSLER, M. G.; CIOTTI, A.M.; SILVEIRA, I. C. A.; SOUSA, S. H. M.; FIGUEIRA, R. C. L.; TASSINARI, C. C. G., FURTADO, V. V.; PASSOS, R. F. Hydrodynamically driven patterns of recent sedimentation in the shelf and upper slope off Southeast Brazil. Continent. Shelf Res., v. 24, p. 16851697, 2004.

MAHIQUES, M. M.; BÍCEGO, M. C.; SILVEIRA, I. C. A.; SOUSA, S. H. M.; LOURENÇO, R. A.; FUKUMOTO, M. M. Modern sedimentation in the Cabo Frio upwelling system, Southeastern Brazilian shelf. An Acad. Bras. Ciênc., v. 77, p. 535-548, 2005.

MAHIQUES, M. M.; WAINER, I. K. C.; BURONE, L.; NAGAI, R.; SOUSA, S. H. M.; FIGUEIRA, R. C. L.; SILVEIRA, I. C. .A. DA; BÍCEGO, M. C.; ALVES, D.P.V.; HAMMERB, Ø. A high-resolution Holocene record on the Southern Brazilian shelf: Paleoenvironmental implications. Quat. Intern., v. 206, p. 52-61, 2009.

MARTIN, L.; SUGUIO, K. Excursion route along the coastline between the town of Cananéia (state of São Paulo) and Guaratiba outlet (state of Rio de Janeiro). In: INTERNATIONAL SYMPOSIUM ON COASTAL EVOLUTION IN THE QUATERNARY. São Paulo: Institute of Geosciences of the University of São Paulo, 1978.

MARTIN, L.; BITTENCOURT, A. C. S. P.; VILAS-BOAS, G. S. Primeira ocorrência de corais pleistocênicos da costa brasileira: datação do máximo da penúltima transgressão. Ciênc. Terra, v. 1, p. 16-17, 1982.

MARTIN, L.; BITTENCOURT, A. C. D. P.; DOMINGUEZ, J. M. L. Oscillations or not oscillations, that is the question: Comment on Angulo, R. J. and Lessa, C. C. "The Brazilian sea-level curves: A critical review with emphasis on the curves from the Paranagua and Cananeia regions" [Mar. Geol. 140, 141-166]. Mar. Geol., v. 150, p. 179-187, 1998.

MARTIN, L.; DOMINGUEZ J. M. L.; BITTENCOURT, A. C. S. P. Fluctuating Holocene sea levels in eastern and southeastern Brazil: Evidence from multiple fossil and geometric indicators. J. coast. Res., v. 19, p. 101-124, 2003.

MELO, M. S. A Formação Pariquera-Açu e depósitos relacionados: sedimentação, tectônica e geomorfogênese. 1990. 211 p. Thesis. University of São Paulo, 1990

MILLIMAN, J. D.; BARRETTO, H. T. Background. Upper continental margin sedimentation off Brazil. Contr. Sedimentol., v. 4, p. 1-10, 1975.

PETRI, S.; SUGUIO, K. Some aspects of the Neocenozoic sedimentation in the Cananéia-Iguape lagoonal region, São Paulo, Brazil. Estud. Sedimentol., v. 1, p. 25-33, 1971

PETRI, S.; SUGUIO, K. Stratigraphy of the IguapeCananéia lagoonal region sedimentary deposits, São Paulo, Brazil, Part II: Heavy mineral studies, microorganisms inventories and stratigraphical interpretations. Bol. Inst. Geociênc., USP, v. 4, 71-85, 1973.
PIOLA, A. R.; CAMPOS, E. J. D.; MÖLLER JR., O. O.; CHARO, M.; MARTINEZ, C. Subtropical shelf front off Eastern South America. J. Geophys. Res., v. 105, C3, p.6565-6578, 2000.

ROCHA, J.; MILLIMAN, J. D.; SANTANA, C. I.; VICALVI, M. A. Southern Brazil. Upper continental margin sedimentation off Brazil. Contr. Sedimentol., v.4, p.117-150, 1975.

SOUZA, M. C. Estratigrafia e evolução das barreiras holocênicas paranaenses, sul do Brasil. 2005. 95 p. Thesis, Federal University of Paraná, 2005.

SUGUIO, K.; MARTIN, L. Quaternary marine formations of the states of São Paulo and southern Rio de Janeiro. In: INTERNATIONAL SYMPOSIUM ON COASTAL EVOLUTION IN THE QUATERNARY. 1978. Special Publication No. 1. São Paulo: Institute of Geosciences of the University of São Paulo, 1978.

SUGUIO, K.; PETRI, S. Stratigraphy of the IguapeCananéia lagoonal region sedimentary deposits, São Paulo, Brazil, Part I: Field observations and grain size analysis. Bol. Inst. Geociênc. USP, 4, 1-20, 1973.

SUGUIO, K.; MARTIN, L.; BITTENCOURT, A. C. S. P.; DOMINGUEZ, J. M. L.; FLEXOR, J. M.; AZEVEDO, A. E G. Flutuações do nível do mar durante o Quaternário superior ao longo do litoral brasileiro e suas implicações na sedimentação costeira. Rev. Bras. Geociênc., v. 15, p. 273-286, 1985.

VEIGA, F. A. Processos morfodinâmicos e sedimentológicos na plataforma continental rasa paranaense. 2005. 193 p. Thesis, Federal University of Paraná, 2005.

VICALVI, M. A.; COSTA, M. P. A.; KOWSMANN, R. O. Depressão de Abrolhos: uma paleolaguna holocênica na plataforma continental brasileira. Bolm Téc. Petrobrás, v. 21, p. 279-286, 1978.

VILLWOCK, J. A.; TOMAZELLI, L. J. Sea-level changes and Holocene evolution in Rio Grande do Sul coastal plain, Brazil. In: INTERNATIONAL SYMPOSIUM ON GLOBAL CHANGES IN SOUTH AMERICA DURING THE QUATEMARY: Past-Present-Future. 1989. São Paulo. Special Publication n. 1, São Paulo: INQUA, p. 192-196, 1989

VILLWOCK, J. A.; TOMAZELLI, J. L.; LOSS, E. L.; DEHNHARDT, C. A.; HORN FILHO, N. O.; BACHI, F. A.; DEHNHARDT, B. A. Geology of the Rio Grande do Sul coastal province. Quat. South Am. Antarct. Penins., v. 4, p. 79-87, 1986.

ZEMBRUSCKI, S. G. Geomorfologia da margem continental sul brasileira e das bacias oceânicas adjacentes. In: CHAVES, H. A. F. (Ed.). Geomorfologia da margem continental brasileira e áreas oceânicas adjacentes. Rio de Janeiro: Petrobrás, 1979. Série Projeto REMAC, 7, p. 129-177.

(Manuscript received 03 June 2009; revised 10 November 2009; accepted 19 February 2010) 